http://dx.doi.org/10.12775/szhf.2019.036

Anna Markwart

Nicolaus Copernicus University in ToRUŃ

E-MAIL: MARKWART.ANNA@GMAIL.COM

ORCID: 0000-0002-2449-1292

\title{
Adam Smith and Sophie de Grouchy on Education ${ }^{*}$
}

\section{Introduction}

When we think about shaping society and raising children, the question of education - understood both as a formal institutional instruction and an informal transfer of values - arises. In this paper, I would like to present views concerning education of two philosophers of the age of the Enlightenment who discussed the drawbacks of the existing education institutions and noticed the importance of education that allows us to grow morally and gain knowledge: Adam Smith's (1723-1790) and Sophie de Grouchy's, Marquise de Condorcet (1764-1822). The paper aims to juxtapose the remarks concerning education made by the two above mentioned philosophers.

This work was supported by the National Science Centre, Poland under Grant 2016/20/S/ HS1/00071. 
According to Jack Russell Weinstein ${ }^{1}$, in terms of Adam Smith's thought, education can be understood in a couple of different ways:

The term 'education' is more ambiguous than is often allowed. It encompasses socialization and acculturation as well as schooling in the formal and informal senses. Philosophy of education as it is traditionally understood by Smith's and our contemporaries concerned itself with the latter, schooling. It investigates familial and institutional instruction that presupposes pedagogical intent.

I intend to address both of those meanings without limiting the discussion to the critique of the existing institutions and methods of education, but I also wish to infer what aims should education serve, on the basis of the analysed works.

Smith's philosophy has been widely discussed since the publication of his first book, The Theory of Moral Sentiments (1759) ${ }^{2}$, and is still a subject of a vivid debate. One of the proofs of Smith's influence on other thinkers are Sophie de Grouchy's Letters on Sympathy. They constitute a commentary to the Theory of Moral Sentiments, which de Grouchy had translated into French (1798). Yet, instead of being a simple summary, the Letters include her own philosophical views. De Grouchy, in her writings, just as Smith does, focuses on the questions of moral philosophy.

The problem of education in Smith's books has rarely been discussed by the scholars ${ }^{4}$. One can find analyses concerning financing institutions for instruction of children and students. During recent years, a few publications mentioning the subject of education have appeared, enriching the discussion concerning Smith's philosophical views. It needs to be emphasized that education has never been the central theme of Smith's thought, "There is [...] no reason to think that Smith had any special interest in philosophy

1 Jack R. Weinstein, Adam Smith's Pluralism. Rationality, Education and the Moral Sentiments (New Haven \& London: Yale University Press, 2013), 82.

2 Adam Smith, The Theory of Moral Sentiments (Indianapolis: Liberty Fund, 1982).

3 Sophie de Grouchy, "Letters on Sympathy", in: Sophie de Grouchy Letters on Sympathy (1798) a Critical Edition, ed. Karin Brown. Transactions of the American Philosophical Society, New Series, Vol. 98, No. 4 (Philadelphia: American Philosophical Society, 2008).

4 Jack R. Weinstein, "Introduction: Adam Smith's philosophy of education", in: Adam Smith Review, vol. 3, ed. Vivienne Brown (London and New York: Routledge, 2007), 51-52. 
of education" ${ }^{\prime \prime}$, there are voices present that Smith provides no positive theory of education ${ }^{6}$, yet, on the other hand, some consider it as "[...] an important subject for Smith, though its economic dimension seems relatively small"7.

Moreover, it is impossible to collect much information on de Grouchy's views concerning education. It needs to be pointed out that we do not have access to the full account of her views on that issue, since her manuscript with a treatise on the subject of education addressed to her daughter is missing. Yet, from the fact that she used to work on such a treatise and from the remarks concerning education present in the Letters on Sympathy, we can infer how important the subject of education was to her. In order to provide a discussion of the philosophers' views on education, one needs to analyse their original works as well as the available literature on the subject.

I aim to address the question of the role of education in Adam Smith's and Sophie de Grouchy's philosophy mentioning not only institutionalized education (the issue discussed by Smith, yet mostly from the economical point of view) but primarily a constant development of norms and our ability to sympathize. Smith's remarks, scattered through his works, addressed the question of universal education and the process of creation of one's morality in relations with other individuals.

Smith's moral philosophy puts emphasis on the role of the social group, family and friends, in the process in which an individual learns social norms and gains the ability to judge one's own and other people's deeds. In my opinion, Smith's stress is laid on an individual and his moral development (which also affects others), though within the possible goals of education, wellbeing of a nation and its prosperity can also be identified. Social and moral norms

5 Weinstein, "Introduction", 56.

${ }^{6}$ Knud Haakonssen, The Science of a Legislator. The Natural Jurisprudence of David Hume and Adam Smith (Cambridge: Cambridge University Press, 1999), 122.

7 P. N. Teixeira, "Dr Smith and the moderns: Adam Smith and the development of human capital theory”, in: Adam Smith Review, vol. 3, ed. Vivienne Brown (London and New York: Routledge, 2007), 151. However, according to Andrew Skinner, Smith's remarks on education need to be considered in the context of his economic thought (Andrew Skinner, Adam Smith: Education as a Public Service, Discussion Papers in Economics No. 9117 (University of Glasgow: Glasgow, 1995), 3). 
are transmitted and undergo change due to interactions between individu$\mathrm{als}^{8}$, therefore Smith regards education, especially that received at home, as crucial. Yet, he also notices the importance of institutional instruction. According to J. R. Weinstein': 'For Smith, education is so fundamental to the development of moral judgement that one can judge the quality of the educational system by examining the moral activities of those who participated in it.

In Smith's Wealth of Nations, we can find a discussion concerning universities as well as the idea of public co-funding of schools for children. He also notices the importance of constant education of adults and mentions the issue of professional training. For Sophie de Grouchy an individual's moral development is very important, but it has a noticeable consequence: becoming better at sympathizing may result in shaping a better, more equal society.

\section{Short Remarks Concerning Sympathy}

In the context of Smith's and de Grouchy's philosophy, it is impossible to discuss either the question of moral and social development or the problem of education without referring to the notion of sympathy. The very beginning of the Theory of Moral Sentiments already provides the reader with this central idea of Smith's work. Using the notions "sympathy" and "fellow-feeling" interchangeably, the philosopher describes how we are able to place ourselves in other people's situation. This way, we can not only imagine the sorrow or happiness of others, but also, using imagination and reason, make an effort and consider whether their actions were adequate to the situation they found themselves in.

8 See more: James R. Otteson, Adam Smith's Marketplace of Life (Cambridge: Cambridge University Press, 2002); Anna Markwart, Bogactwo uczuć moralnych (Toruń: Wydawnictwo Naukowe UMK, 2017).

9 Weinstein, "Introduction", 68. 
Sympathy and an impartial spectator ${ }^{10}$ play a crucial role in Smith's moral theory. To sympathize does not mean to copy the feelings of another person. The crucial role is played by imagination that allows us to place ourselves in a situation of the agent. That does not mean we magically become this person and have the same feelings - that would, according to Smith, be impossible. Using nothing more than our ability to sympathise as well as our knowledge, experience, and feedback from other people, we gradually learn to judge our own and others' behaviour. The philosopher introduces also the impartial spectator who is created by individuals on the basis of their sympathy. We imagine this impartial judge using the knowledge about circumstances of an event as well as all our experience and social norms. While judging someone's actions we try not to think in terms of our self-interest, but to consider what kind of behaviour would be proper.

In my opinion, subtle sympathy and the adequate impartial spectator are not given to us as tools ready to operate with, and the education we receive within the family, society and at school allows us to make them more subtle. We need to put an effort and use our imagination and ability to sympathise in order to create the impartial spectator. With each and every experience we become better at sympathizing ${ }^{11}$. When we reflect and try to go into a position of the impartial spectator, it becomes easier for us and the judgements given can be more accurate. In order to develop such a habit, we need to train and keep trying to become impartial. Smith provides us with examples of sympathy that we feel automatically as well as of sympathy which we need to place in context of the situation before judging properly. He presents an extensive discussion of general rules of morality that we use on a daily basis

10 Both sympathy and an impartial spectator have been widely discussed in the literature on the subject. See e.g.: Alexander Broadie, Agreeable Connections. Scottish Enlightenment links to France (Edinburgh: Birlinn Ltd, 2012); Vanessa Nurock, "Le spectre sympathique: Typologie des formes de sympathie dans la Théorie des sentiments moraux", in: Adam Smith et l'origine du libéralisme, ed. Michaël Biziou (Paris: Presses Universitaires de France, 2003); David D. Raphael, The Impartial Spectator. Adam Smith's Moral Philosophy (Oxford: Clarendon Press, 2009); and many others.

11 Smith presents an interesting analogy between the sense of sight and the ability to imagine the opinion of the impartial spectator. See: Adam Smith, "Of the External Senses", in: Adam Smith, Essays on Philosophical Subjects (Indianapolis: Liberty Fund, 1982); Smith, The Theory of Moral Sentiments. 
to act properly in a socially acceptable way ${ }^{12}$. He notices that it is better to imagine the impartial spectator and behave in a way he would approve; however, most people do not make this effort and simply obey the general rules.

I would like to mention two essential aspects of education understood as upbringing (especially that received at home): the first aspect is that we learn to obey the general rules - those are transmitted to us through socialisation and the other one is that we develop sympathy and make it more subtle. We learn to be moral beings within the society and the education we need to strive for perfection is mostly acquired at home (we learn sympathy from our parents first $)^{13}$ and in informal interactions with other society members. The formal instruction helps us develop those skills; yet, it is not indispensable in this case.

Sophie de Grouchy criticized Smith for his views on sympathy - especially the fact that Smith did not discuss the roots and causes of morality. She pointed out that the role of experiencing physical pain is crucial for perfecting sympathy (from individual pains we experience we can infer an abstract idea of pain which we do not have to necessarily experience ourselves, which leads us to the abstract idea of pain that teaches us morality, makes it impossible for us to become indifferent to pain) and so are family ties that already place us in moral relations that might be repeated in our later life. Sentiments are crucial, yet not sufficient. We need both, emotional reaction (before and after experiencing the moral truth) and reasoning. "Moral sentiments, then, originate in sympathy, and moral ideas originate in reflection"14. However, it needs to be remembered that for de Grouchy our emotional reaction is immediate.

De Grouchy assumed people as good; however, the negative influence of the society can change the way they perceive what is moral and what is not. Social distance is one of the obstacles we need to overcome; the other one is the fact that, since childhood, people become accustomed to seeing

12 Charles L. Griswold, Adam Smith and the Virtues of Enlightenment (Cambridge: Cambridge University Press, 2012), 185-186; Smith, The Theory of Moral Sentiments, 161-170.

13 Adam Smith, Lectures on Jurisprudence (Indianapolis: Liberty Fund, 1982), A. III.5.

14 Karin Brown, Sophie de Grouchy Letters on Sympathy (1798) a Critical Edition, Transactions of the American Philosophical Society, New Series, Vol. 98, No. 4 (Philadelphia: American Philosophical Society, 2008), 32. 
privileges of ones and misfortunes of others. It is sympathy that motivates us to act morally and benevolently: "Ideas of good and evil [...] emerge when reflecting on feelings of right and wrong. De Grouchy argues that when we submit sentiments to the scrutiny of reason we thus obtain ideas of good, evil, justice, and rights" ${ }^{15}$. Moreover, "In the Letters de Grouchy argues that sentiments need to be exercised because otherwise they will diminish. She also thinks that feelings for others, once developed, should become a matter of regular practice and habit"16 - and de Grouchy's view leaves us with room for changing moral views and perfecting our moral reactions. Sympathy, according to de Grouchy is developed in social relations and between people. She emphasized how important the role played by education could be; unfortunately, it is not. Her critique of institutions for instruction that teach performing tasks instead of understanding them is strictly connected to the idea that they could actually be a factor that lets us become better when it comes to moral judgements.

\section{Institutions for Instruction}

Both of the discussed philosophers briefly mentioned the question of the institutions for instruction. Alexander Broadie ${ }^{17}$ in his brilliant analysis of Smith's and de Grouchy's thought has stated that:

[...] the question of the most effective forms of education for producing sympathetic people is an important field of investigation in the Letters. Education does not, on the other hand, figure significantly in the TMS. It is not that Smith believes we cannot engage in a process of cultivating or refining our sympathetic responses, and of strengthening them [...].

\footnotetext{
15 Ibidem, 30.

16 Ibidem, 95.

17 Broadie, Agreeable Connections, 142-143.
} 
I agree with Broadie that Smith does not explicitly state how to organize education that would benefit our moral development; yet, I believe we can infer some clues on what is important from the philosopher's remarks.

Smith considers education as one of the government responsibilities which proves how important this issue must have been for him. He presents an extensive discussion on schooling in An Inquiry into the Nature and Causes of the Wealth of Nations ${ }^{18}$. He also repeatedly mentions the subject in his Lectures on Jurisprudence.

The Scottish philosopher is quite critical when it comes to universities. One of the subjects he focuses on is rather an economic one: the question of financing them ${ }^{19}$. He discusses two models of funding. One is based on public financing or on the fact that a university receives funds and pays salaries to its teachers. In the other one, students fully or partially pay a teacher for classes (this system, praised by Smith, was applied in the University of Glasgow, which Smith attended ${ }^{20}$. Two main issues appear in the philosopher's considerations concerning this matter: the first issue is the flow of funds to the university and the other one is what effect the method of financing teachers' work has on the quality of classes.

The author of the Wealth of Nations, as in other numerous aspects discusses in the book, writes favourably on competition. Therefore, he criticizes the system of fixed salaries and full public funding. According to Adam Smith, even bursaries or scholarships are not a satisfying solution as they tend to tie the students to given universities, colleges or schools, thus limiting the competition between them. When institutions or individual teachers need to compete offering better-quality classes in order to gain the students, the

18 Adam Smith, An Inquiry into the Nature and Causes of Wealth of Nations (Indianapolis: Liberty Fund, 1981).

19 Smith, An Inquiry..., V.1.3.II.18-48. When discussing the question of universities, Smith mentions the issue of what was and is being taught. He provides a short analysis how the philosophy and law changed as subjects of teaching. He notices that the first purpose of the universities was to prepare clergymen and the teaching program was created to serve their purpose. However, his remarks on this subject are not essential for the purposes of this paper.

${ }^{20}$ On the other hand, Smith was critical of the Oxford University which he became acquainted with as a student. The system of fixed salaries was applied there. Scottish universities of the day had great teachers and a very high level of classes taught. 
level of lectures augments ${ }^{21}$. Fixed salaries provide no motivation to improve competencies or to prepare extensively for classes, as the teachers are paid no matter how valuable or worthless their lectures are.

For Smith, it is always important to transmit knowledge in the way that would be adjusted to the audience and to the goal of the speech (or of the book). One of the main themes of his Lectures on Rhetoric and Belles Lettres ${ }^{22}$ is the question of the appropriate style. The philosopher lists three different styles, including the "didactick" one. The writer or speaker who uses it needs to reach students and present a clear argument, utilising divisions and subdivisions $^{23}$. Therefore, Smith's interest is not only how a teachers' work is organised, but also remembering about the proper way of presenting knowledge Smith's Theory of Moral Sentiments is itself a great example of his opinions on that matter.

Critical comments de Grouchy makes in her Letters on Sympathy are mostly focused on the way the knowledge is being transmitted. She notices how children are taught, i.e. in a way that does not promote the real understanding of the issues discussed but rather focuses on definitions. As she observes, this sometimes causes chaos in children's minds as they frequently learn without internalising the ideas discussed. As she underlines, giving the example of teaching grammar:

One of the primary goals of education should thus be to provide the ability to acquire general ideas and to experience these abstract and general sentiments I have discussed. Ordinary education usually distances itself from this goal. The study of grammar precedes all others and, it is true, begins (if children understand it) by offering them a few metaphysical ideas. But in their totality these ideas are the most mistaken or at least the most incoherent ${ }^{24}$.

When reminding the readers of those drawbacks of learning by heart instead of giving children the possibility to understand, de Grouchy tends to mention the goals education should be serving: to understand moral and

\footnotetext{
${ }^{21}$ Smith, An Inquiry..., IV.1.3.II.10-13.

22 Adam Smith, Lectures on Rhetoric and Belles Lettres (Indianapolis: Liberty Fund, 1985).

23 Smith Lectures on Rhetoric..., lectures: 7,24.

24 de Grouchy, "Letters on Sympathy", 116.
} 
social rules, perfect the ability of abstract thinking and recognize the truth. Education is not to solely provide the tools for mechanical doing one's job it is to help an educated person become a better, more sensitive moral being.

\section{Constant and Universal Education}

When discussing the question of the division of labour, Smith mentions the importance of education - especially constant education. In the age of manufactures, repetitive tasks which are frequently quite simple or become a numbing routine, on the one hand, make people more efficient and increase production but, on the other hand, strongly affect workers. Such work causes a kind of "torpor" of their minds, limiting their activities to one task. The Scottish philosopher notices numerous drawbacks of such a situation: limitation of the workers' courage, social and rhetoric skills etc. ${ }^{25}$ As the antidote, Smith suggests education supported by the state that would allow adult workers (and earlier children who would become workers in the future) to keep their minds open. According to Emma Rothschild:

Smith describes a strikingly unequal distribution, in rich countries, of the experience of what he calls 'variety'. There is certainly a great deal of variety within the society as a whole, and for some individuals, there is an 'almost infinite variety of objects'. But for others, there is virtually no variety at all. Smith concludes that the education of ordinary or common people is a matter of far greater public concern than the education of people of 'rank', whose employments of seldom 'harass them from morning to night'. The lack of education is indeed a principal source of the inequality which develops in the early years of children's lives ${ }^{26}$.

At the same time, the philosopher argues against funding apprenticeships for youngsters or adults, as he treats them rather as an investment in one's

25 Adam Smith, Lectures on Jurisprudence (Indianapolis: Liberty Fund, 1982), 330.

26 Emma Rothschild, "Condorcet and Adam Smith on Education and Instruction", in: Philosophers on Education, ed. Amelie O. Rorty (London: Routledge, 1998), 210. 
future. Apprenticeship is to teach a job that would be profitable in the future ${ }^{27}$ and would thus repay the free work (and sometimes even the necessity to pay others to allow us to work). In this sense, instruction is to impact the state wellbeing through preparing skilled workers and specialists. Yet, it is up to them to find an occupation profitable enough that would be worth the effort of doing the apprenticeship. Moreover:

Education was expected to facilitate the working of the overall economic system because educated people would be more likely to move from one employment to another, to take risks, to free themselves from the superstitious regard for old customs and regulations, and in general to behave in the independent manner which was associated with modern commercial relations. The effect of education would be also to make people more enlightened about their own self-interest; they would see more clearly wherein their interest lay ${ }^{28}$.

Smith is not in favour of sending small children to boarding schools. The main argument is that such a practise makes it almost impossible to raise children in a way that would teach them to be loving and respectful for their parents and family. Though the quality of classes might be higher in distant schools, it does not outweigh children's happiness. We need to remember that institutions for instruction were created by men whereas family - by Nature. At the same time, he does not assume the existence of schools to be superfluous - the co-existence of the both mentioned environments is essential for good education.

For the philosopher, it was important to give children an opportunity to gain basic education. It is quite well-rooted in his view on a human being, as he believes that these are our experiences and things we learn that shape our faculties and that children are generally open to knowledge and willing to learn. Providing children with universal education requires, according to Smith, the intervention of the state. Organized schools, co-financed by the government, should provide access to all children, no matter what their wealth is, in order to teach them basic skills such as reading, writing, and

\footnotetext{
27 Smith, An Inquiry..., I,10.I.4.

28 Rothschild, “Condorcet and Adam Smith...”, 213
} 
counting. Weinstein ${ }^{29}$ even suggested that without education one's happiness, sympathy and ability to be prudent cannot be reached. According to him ${ }^{30}$ :

Despite his call for some competition, Smith also argues that education serves the needs of the wider community, and the public must therefore pear a proportion of the expense; Smith does not say how much. The poor should receive incentives to educate themselves and their children, a prescription that is sure to increase the financial burden on the community. Herein lay the difficulties in Smith's economics of education.

Smith based his views on the system of parish schools that existed in Scotland of his days ${ }^{31}$, which even poor children were able to attend, receiving education together with those whose parents could afford paying for classes. As Kennedy wrote:

The expense of educating youth should be met either from the general revenue of society or from the parents or guardians of the beneficiaries. Smith found himself in a bind here, as he believed that services offered in return by teachers for a salary, paid by taxation, private endowments, charities or legacies, would deteriorate to the point of indifference in their quality ${ }^{32}$.

Smith views on the Scottish model of education were quite biased, as Maria Pia Paganelli shows in her paper ${ }^{33}$. As a Scotsman who praised the solution introduced in his Motherland, he, according to Paganelli, omitted limitations and shortcomings of the schooling and university systems. She argues, for example, that scholarships assigned to universities, unlike what the author of the Theory of Moral Sentiments suggested, would still prefer a better university even if it would not offer them a scholarship. However, although Paganelli makes some interesting points concerning Smith's biased views, in my opinion, the fact that he tended to idealise the way parish schools were or-

29 Weinstein, "Introduction", 102-104.

30 Weinstein, Adam Smith's Pluralism, 186.

31 Rothschild, "Condorcet and Adam Smith...", 210.

32 Gavin Kennedy, Adam Smith. A Moral Philosopher and His Political Economy (New York-Hampshire: Palgrave Macmillan, 2008), 169.

${ }_{33}$ Maria Pia Paganelli, "Smith and the Scottish model of education", in: Adam Smith Review, vol. 10 (2018), 92-104. 
ganised and funded in Scotland (as well as the way universities were financed, etc.) was not only affected by his willingness to present Scotland as a prospering country in which education flourished, but also due to the fact that it fitted his economic and philosophical principles, especially the idea of the freedom of choice of one's resources allocation.

Moreover, according to the author of the Wealth of Nations, giving even small scholarships to apt children and supporting universal education at least on the basic level would most definitely benefit them. As Smith notices, even if the state would have no gain from providing schools for people of lower states, it cannot mean that it should not care for having them properly educated.

For the state, there are some additional benefits from having educated citizens: the more educated they are, the less they are susceptible to religious enthusiasm and superstitions, more likely to show and receive respect and to obey the rules that are common in the society, "Smith recognised the point that in the modern state it is critically important that the citizen be vigilant, informed, above all else - educated, in the broad sense of that term, if an adequate standard of political behaviour is to be sustained" 34 . They are better at making market decisions and more likely to find a suitable occupation. It is to be mentioned that de Grouchy must have also been in favour of constant and adult education as, together with the Marquis de Condorcet, she took part in establishing the Lycee in Paris, which was aimed at educating adults - lectures on various subjects such as mathematics and history were given there ${ }^{35}$. Smith puts special emphasis rather on the well-being and development of individuals whose minds should be kept active and critical and who need to be given tools to live independent lives. The goal of the schooling system is never to prepare children to be absent-minded, efficient workers. It is the very opposite - to encourage them to learn and strive for perfection.

It cannot be, however, assumed that Smith did not notice the effects of education that are positive for the nation and the society. He appealed to both, the readers' sense of humanity and their care for political stability when

34 Andrew Skinner, Adam Smith: Liberalism and Education, University of Glasgow Discussion Papers in Economics No. 9002 (Glasgow, 1990), 3.

35 Brown, Sophie de Grouchy..., XXII. 
discussing universal education - asking for public money requires pointing out some public benefit ${ }^{36}$. Becoming well-educated citizens who possess certain skills allowing them to perform useful jobs, move from one employment to another, defend their country, invest, and make the effort to give proper moral judgements is good for the society: "People become, through education, better individuals and better citizens" ${ }^{37}$.

For Sophie de Grouchy, it is important to provide children with proper education, as it not only helps them to gain certain skills, but also affects their moral and social development. As Karin Brown noticed:

Although she does not develop a complete theory of education in the Letters, de Grouchy lays heavy emphasis on moral education. The goal of education for her is acquiring this power of abstraction both intellectually and emotionally. She blames educators for teaching children logic and grammar while neglecting to develop their sensitivity and consideration of others ${ }^{38}$.

Teaching the rules of morality without teaching how to reach them is not what de Grouchy would like to be happening. Since morality requires not only emotions but also reasoning and ability to generalize, we need to train the latter. Ready answers and learning by heart are not the proper path. The schooling system could be very useful and could help people become better citizens and moral beings, teach them how to strive for the truth and shape the society. According to de Grouchy:

How many times in a century does education succeed in inculcating the mental strength and rectitude necessary to arrive at abstract ideas? How many times has education perfected an instinct for truth? Has it strengthened the tendency to follow truth alone and to be ceaselessly nourished by it? How many times, on the contrary, does education mislead us in the byways of routine and convention, from prejudice to prejudice and from error to error? How many times has it not transformed, for example, the need we have of living exclusively through useful, true, and wide-ranging activities to which nature calls our minds and

36 Weinstein, "Introduction", 62; Kennedy, Adam Smith, 170 - though, as I agree with Emma Rothschild, it was not the goal itself.

37 Weinstein, "Introduction", 70.

38 Brown, Sophie de Grouchy..., 33. 
hearts into that of living only for the deceptive and narrow-minded pleasures of pride and vanity? Indeed! ${ }^{39}$

Moral sentiments need to be learned by examples while negative experience and lack of education can strongly affect our performance and make us immune to the pain of others - the very source of sympathy. The knowledge we can obtain at school can provide us with the tools we need to critically observe the society and to reach moral and intellectual conclusions on our own.

\section{Conclusions}

Although de Grouchy criticized Smith's understanding of sympathy, she based on his ideas and emphasized how important it is to put effort into developing our ability to sympathize. The latter idea is, in my opinion, present also in Smith's thought. Both of the philosophers noticed that sympathy grows in social relations and it could be altered (both negatively and positively) by experience and influences we encounter. Moreover, shaping morality in the family and strong family ties play an important role for the both thinkers. The institutional instruction also plays a part in their philosophy - although it is quite different for each of them.

For Smith, an individual striving for perfection was the goal, and shaping the society was partly an unintended consequence. We cannot influence a society as a whole. Yet, actions influence other individuals. Education can give people, especially the poor ones, the possibility to work and act in a way that would be profitable for the society, but also, which I find even more important, to grow intellectually and morally.

Smith underlined the importance of family ties and home education, so the picture we are to see is a network of schools co-financed by the state where poor students would be given, at least partially, scholarships enabling them to share the costs of their basic education. Afterwards, there

39 de Grouchy, "Letters on Sympathy", 156. 
should be a possibility to continue education - either at universities or during professional training; yet, those should be paid by students. Moreover, paying teachers encourages them to be better prepared for their students; otherwise, the latter would take their money and go wherever they would be able to obtain classes of higher quality. It seems that what Smith was in favour of is more giving people a possibility to become wider-minded, more open, and better than to be simply better servants and workers. His emphasis was put rather on individuals' needs and not on those of the society.

For de Grouchy, sympathy needs to be learned and education plays an important role here. However, we should not be taught solely the systems of morality, but rather be given tools to find the truth and develop moral faculties on our own. She does not give us the overview of institutions for instruction in her Letters on Sympathy, yet, it is to be seen that both girls and boys should be given an opportunity to learn.

One other question arises: why is it so important to keep referring to the philosophy of Adam Smith and Sophie de Grouchy? Apart from the answers that justify studying the history of philosophy per se, one additional issue appears: Smith and de Grouchy leave us with an important clue for organising institutions for instruction. These are individuals and their wellbeing we are to focus on. A social change is possible only through individuals, and their education can contribute to that extensively. What I consider to be crucial is the fact that we do have ready solutions, general rules of morality and knowledge to learn by heart, but what Smith and de Grouchy cherished most and considered students to be capable of achieving is critical thinking that requires skills transmitted through formal education $^{40}$.

I infer that, for Smith, it was important since he considered the effort to use the construct of an important spectator as a better solution than simply following general rules of morality. Skills that allow us to do that and the experience of variety that leaves us with open minds that are the most

40 A similar view that all children should be taught to analyse and understand rather than simply obey is also present in Nicolas de Condorcet's writings. For an interesting comparison of Smith's and Condorcet's views on education see: Rothschild, "Condorcet and Adam Smith.... 
important to be taught - not only when it comes to children (whose education is of the highest essence and should be the responsibility of us all) but throughout people's entire life. I would like to conclude with de Grouchy's own words:

Fathers, mothers, teachers, the destiny of the generation who will follow you is virtually in your hands! Guilty you will be if you let miscarry in your children the precious seeds of sensibility, which await, for their development, the sight of pain, the example of compassion, the tears of gratitude, and an enlightened hand to kindle them and stir them up ${ }^{41}$.

\section{Bibliography}

Broadie Alexander. 2006. "Sympathy and the Impartial Spectator". In: The Cambridge Companion to Adam Smith. Ed. Knud Haakonssen, 158-188. New York: Cambridge University Press.

Broadie Alexander. 2012. Agreeable Connections. Scottish Enlightenment links to France. Edinburgh: Birlinn Ltd.

Brown Karin. 2008. Sophie de Grouchy Letters on Sympathy (1798) a Critical Edition, Transactions of the American Philosophical Society. New Series. Vol. 98. No. 4. Philadelphia: American Philosophical Society.

Griswold Charles L. 2012. Adam Smith and the Virtues of Enlightenment, Cambridge: Cambridge University Press.

De Grouchy Sophie. 2008. "Letters on Sympathy". In: Sophie de Grouchy Letters on Sympathy (1798) a Critical Edition. Ed. Karin Brown. Transactions of the American Philosophical Society. New Series. Vol. 98. No. 4. Philadelphia: American Philosophical Society.

Haakonssen Knud. 1999. The Science of a Legislator. The Natural Jurisprudence of David Hume and Adam Smith, Cambridge: Cambridge University Press.

Kennedy Gavin. 2008. Adam Smith. A Moral Philosopher and His Political Economy. New York/Hampshire: Palgrave Macmillan.

Markwart Anna. 2017. Bogactwo uczuć moralnych. Toruń: Wydawnictwo Naukowe UMK.

Nurock Vanessa. 2003. "Le spectre sympathique: Typologie des formes de sympathie dans la Théorie des sentiments moraux". In: Adam Smith et l'origine du libéralisme. Ed. Michaël Biziou, Paris: Presses Universitaires de France.

${ }^{41}$ de Grouchy, "Letters on Sympathy", 112. 
Otteson James R. 2002. Adam Smith's Marketplace of Life, Cambridge: Cambridge University Press.

Paganelli Maria Pia. 2018. "Smith and the Scottish model of education". In: Adam Smith Review. Vol. 10. Ed. Fonna Forman, London: Routledge. 92-104.

Raphael David D. 2009. The Impartial Spectator. Adam Smith's Moral Philosophy, Oxford: Clarendon Press.

Rothschild Emma. 1998. "Condorcet and Adam Smith on Education and Instruction". In: Philosophers on Education. Ed. Amelie O. Rorty, London: Routledge, 208-225. Skinner Andrew. 1990. Adam Smith: Liberalism and Education. University of Glasgow Discussion Papers in Economics. No. 9002: Glasgow.

Skinner Andrew. 1995. Adam Smith: Education as a Public Service. University of Glasgow Discussion Papers in Economics. No. 9117: Glasgow.

Smith Adam. 1981. An Inquiry into the Nature and Causes of Wealth of Nations. Indianapolis: Liberty Fund.

Smith Adam. 1982. "Of the External Senses". In: A. Smith, Essays on Philosophical Subjects. Indianapolis: Liberty Fund.

Smith Adam. 1982. Lectures on Jurisprudence. Indianapolis: Liberty Fund.

Smith Adam. 1982. The Theory of Moral Sentiments. Indianapolis: Liberty Fund.

Smith Adam. 1985. Lectures on Rhetoric and Belles Lettres. Indianapolis: Liberty Fund.

Teixeira P. N. 2007. "Dr Smith and the moderns: Adam Smith and the development of human capital theory". In: Adam Smith Review. Vol. 3. Ed. Vivienne Brown, 139-158. London and New York: Routledge.

Weinstein Jack R. 2007. "Introduction: Adam Smith's philosophy of education". In: Adam Smith Review. Vol. 3. Ed. Vivienne Brown, 51-74, London \& New York: Routledge.

Weinstein Jack R. 2013. Adam Smith's Pluralism. Rationality, Education and the Moral Sentiments. New Haven \& London: Yale University Press.

\section{Abstract}

The paper analyses Adam Smith's and Sophie de Grouchy's views concerning education. It addresses both the issues of formal education in institutions for instruction as well as it mentions an informal transfer of values within the family and the society. The brief characteristic of the notions of sympathy and an impartial spectator precedes the discussion of the goals education should serve. It is an individual's development that is the core issue of the thinkers' considerations. The benefits for the society, at least in Smith's case, are important, yet subordinate. Both of the philosophers presented a critique of existing educational institutions. Smith's 
views on ways of financing universities and schools are also summarized in the paper. Moreover, a discussion on the issues of educating children and adults is presented, mentioning the importance of universal access to knowledge. It is the idea that people need to achieve the ability to think critically and not to learn the rules (also those of morality) by heart that marks the significance of Smith's and de Grouchy's philosophy of education.

Keywords: Adam Smith, Sophie de Grouchy, sympathy, education 